\title{
Population structure, distribution and harvesting of southern geoduck, Panopea abbreviata, in San Matías Gulf (Patagonia, Argentina)
}

\author{
ENRIQUE MORSAN ${ }^{1}$, PAULA ZAIDMAN ${ }^{1,2}$, MATÍAS OCAMPO-REINALDO $^{1,3}$ \\ and NÉSTOR CIOCCO ${ }^{4,5}$ \\ ${ }^{1}$ Instituto de Biología Marina y Pesquera Almirante Storni, Universidad Nacional del Comahue, Guemes 1030 , \\ 8520 San Antonio Oeste, Río Negro, Argentina. E-mail: qmorsan@gmail.com \\ ${ }^{2}$ CONICET-Chubut. \\ ${ }^{3}$ CONICET. \\ ${ }^{4}$ IADIZA, CCT CONICET Mendoza, C.C. 507, 5500 Mendoza, Argentina. \\ ${ }^{5}$ Instituto de Ciencias Básicas, Universidad Nacional de Cuyo, 5500 Mendoza Argentina.
}

\begin{abstract}
SUMMARY: Southern geoduck is the most long-lived bivalve species exploited in the South Atlantic and is harvested by divers in San Matías Gulf. Except preliminary data on growth and a gametogenic cycle study, there is no basic information that can be used to manage this resource in terms of population structure, harvesting, mortality and inter-population comparisons of growth. Our aim was to analyze the spatial distribution from survey data, population structure, growth and mortality of several beds along a latitudinal gradient based on age determination from thin sections of valves. We also described the spatial allocation of the fleet's fishing effort, and its sources of variability from data collected on board. Three geoduck beds were located and sampled along the coast: El Sótano, Punta Colorada and Puerto Lobos. Geoduck ages ranged between 2 and 86 years old. Growth patterns showed significant differences in the asymptotic size between El Sótano (109.4 mm) and Puerto Lobos $(98.06 \mathrm{~mm})$. The maximum age decreased from north to south. Natural mortality was estimated for each bed according to a catch curve $\left(M=0.105-0.177 \mathrm{yr}^{-1}\right)$, with a method based on mean age $\left(M=0.212-0.233 \mathrm{yr}^{-1}\right)$ and a method based on maximum longevity recorded $\left(M=0.062-0.13 \mathrm{yr}^{-1}\right)$. Population features were integrated into the harvest analysis to generate a preliminary management proposal that includes subdivision of the coastal zone, limited entry, harvest rate and individual vessel quotas.
\end{abstract}

Keywords: geoduck, clams, fishery, ageing, population structure, growth, natural mortality.

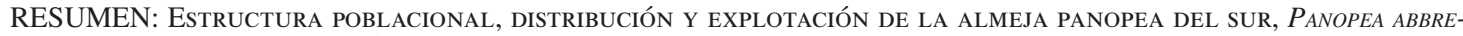
Viata, en el Golfo San Matías (Patagonia, Argentina). - La almeja panopea del sur es el bivalvo más longevo bajo explotación en el Atlántico Sur y es objeto de explotación artesanal mediante buceo en el Golfo San Matías. Salvo datos preliminares de crecimiento y un estudio del ciclo gametogénico, se carece de información relevante para el manejo del recurso como estructura poblacional, mortalidad y diferencias interpoblacionales de crecimiento. Los objetivos de este trabajo fueron analizar la distribución espacial de datos de relevamientos, la estructura poblacional, el crecimiento y la mortalidad en bancos situados a lo largo de un gradiente latitudinal a partir de determinación de edad mediante secciones delgadas de valvas. También se describe la distribución espacial del esfuerzo pesquero de la flota y sus fuentes de variabilidad a partir de datos colectados a bordo. Tres bancos de panopea fueron localizados y muestreados a lo largo de la costa: El Sótano, Punta Colorada y Puerto Lobos. La edad de los individuos osciló entre 2 y 86 años. El patrón de crecimiento mostró diferencia significativa entre la talla asintótica en El Sótano $(109.4 \mathrm{~mm})$ y Puerto Lobos $(98.06 \mathrm{~mm})$. La edad máxima evidenció una tendencia decreciente Norte - Sur. La mortalidad natural fue estimada en cada banco mediante curva de captura $(M=0.105$ a 0.177 año $\left.^{-1}\right)$, un método basado en la edad media $\left(M=0.212\right.$ a 0.233 año $\left.^{-1}\right)$ y un método basado en la longevidad máxima registrada $\left(M=0.062\right.$ a 0.13 año $\left.{ }^{-1}\right)$. Las características de la población se integraron al análisis de la explotación para generar una propuesta de gestión que incluye subdivisión de las zonas costeras, entrada limitada, tasa de cosecha y cuotas individuales por embarcación.

Palabras clave: panopea, almeja, pesquería, edad, estructura poblacional, crecimiento, mortalidad natural. 


\section{INTRODUCTION}

Small scale fisheries for bivalves ("S fisheries", Orensanz et al., 2005) are important in Argentina and contribute to the subsistence of thousands of fishermen and their families along the coast. In San Matías Gulf (SMG, Patagonia Argentina) (Fig. 1), these fisheries use dredges and diving. During the period from 1970 to 1993, the convergence of factors such as spasmodic recruitment, availability of resources and strong market possibilities produced a pulse fishery that expanded until the collapse of the scallop and mussel stocks (Morsan, 2008). As a consequence of the "boom-bust" cycles of fisheries in relation to target species, several shellfish species, such as the purple clam (Amiantis purpurata; Morsan, 2003, 2007), southern geoduck (Panopea abbreviata; Ciocco, 2000; Morsan and Ciocco, 2004), crabs (Platyxanthus patagonicus and Ovalipes trimaculatus; Leal et al., 2008) and snails (Buccinanops globulosum; Narvarte, 2005) began to be studied in order to promote sustainability of the artisanal fishery based on diversification, limited entry and a reallocation of fishing effort.

The southern geoduck fishery was encouraged by the high prices of geoduck from the North Pacific (Panopea abrupta) on the Japanese market. This species has annual landings of about $5000 \mathrm{t}$ on the coasts of NW USA and SW Canada (Bradbury and Tagart, 2000; Campbell et al., 1998). The destinations of $P$. abbreviata landings are Hong Kong and Japan and the local Chinese community.

Geoducks are suspension-feeding bivalves characterized by a life cycle in which pelagic larvae are produced from very long-lived and sedentary spawning adults that occupy a range of marine habitats (Goodwin and Pease, 1989; Van der Molen et al., 2007). The southern geoduck, $P$. abbreviata, is a hiatellid clam endemic to the SW Atlantic, distributed from Río de Janeiro $\left(23^{\circ} \mathrm{S}\right)$ to Puerto Deseado $\left(48^{\circ} \mathrm{S}\right)$. Beds are distributed from shallow waters to depths of $75 \mathrm{~m}$ (Scarabino, 1977). It lives buried deeply in sand and mud substrates down to $40 \mathrm{~cm}$. The gametogenic cycle of $P$. abbreviata is continuous with no resting period (Van der Molen et al., 2007). Morsan and Ciocco (2004) studied age and growth from thin sections of 104 valves coming from a then unexploited bed, and estimated longevity as 40 years. Southern geoducks grow rapidly during the first 9 to 12 years, attaining $89-94 \%$ of their maximum size $\left(\mathrm{L}_{\infty}=101.6 \mathrm{~mm}\right)$. A similar pattern was described for $P$. abrupta, which has a potential life span of 186 years (Strom, 2003) and may reach a whole live weight of up to $3 \mathrm{~kg}$ (Goodwin and Pease, 1989). Growth rate in this species varies substantially along environmental gradients and between geographic regions (Goodwin and Pease, 1989; Hoffmann et al., 2000; Bureau et al., 2002). Even though there are no studies of $P$. abbreviata growth for other localities in SMG we assume that there are variations related to environmental conditions. There are no estimations of natural mortality of southern geoduck but, given its longevity, it is most probably low. For $P$. abrupta, estimates of the natural mortality coefficient fall within the range of 0.014 to $0.054 \mathrm{yr}^{-1}$ (Orensanz et al., 2004).

The fishery for southern geoduck began in North Patagonia during 1999 under experimental conditions based on artisanal diving. The artisanal fleet is composed of small, outboard-powered boats (less than 10 $\mathrm{m}$ long) that access the fishing grounds from the beach after navigating less than $5 \mathrm{~nm}$. During the exploratory phase of the fishery some areas with high density were located within the San Matías and San José Gulfs. The individual weight (up to $1.4 \mathrm{~kg}$ ) and meat quality made southern geoduck a potential product for external markets and drove the fishery to commercial development.

However, the high prices are outweighed by the uncertainty about spatial distribution and biological aspects that determine the population dynamics (fecundity, maturity-at-age, mortality, growth rate variability). Together with abundance estimation, these basic aspects of population dynamics are necessary for establishing a harvest guideline, usually in the form of a harvest rate. The effects of uncertainty about the actual biomass in this kind of resource have been discussed by Hilborn (2002). As there is no convenient way to survey geoducks over large areas, the choices are annual surveys of actual biomass in small areas or very coarse updates of estimated virgin biomass over broad areas (Orensanz et al., 2004). In the first case, the estimates are based on the bed area, which is difficult to define. In addition, geoducks are difficult to detect because they retract their siphons into the sediment and their presence can go unnoticed by divers. However, sampling surveys based on direct visual recordings of geoducks along line transects are frequently used to detect spatial aggregations and assess the stock of this kind of resource (Bradbury et al., 2000, Pritchett, 2003, Siddon, 2007). The difference between counts and accurate density is known as the "show factor" and is affected by the type of sediment, season and geoduck size. The case of the southern geoduck represents an additional challenge: until 1999, their presence was largely ignored by fishermen, and their concentration was never monitored by surveys (focused on epifaunal resources). Ciocco et al. (2001) conducted an independent experiment on the coastal geoduck bed of San José Gulf to estimate the difference between tips counted by divers during preliminary surveys in four quadrats, and the maximum number of thoroughly counted tips in these same quadrats. The mean difference determined between diver survey counts and accurate densities recorded in each quadrat was 1.414 , with the maximum difference being between 2.3 and 2.5 times the number of geoducks obtained from survey counts.

In this study we describe for the first time the spatial distribution of southern geoduck along the coast of San Matías Gulf. We carried out previous age determination studies to provide the basis for understanding 


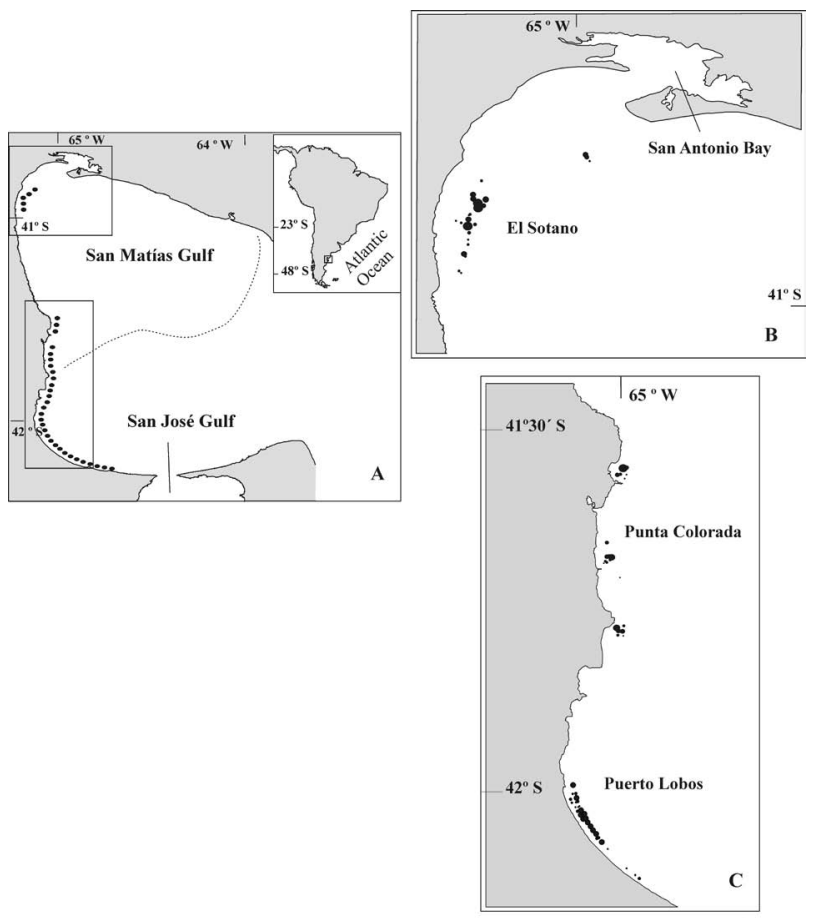

FIG. 1. - A, location of the sampling sites in San Matías Gulf and geographic distribution of the southern geoduck, Panopea abbreviata, on the Atlantic coast $\left(23^{\circ} \mathrm{S}-48^{\circ} \mathrm{S}\right)$. Black dots represent the region of the coast surveyed during 2000-2003, and the dotted line shows the position of the thermohaline front; $B$ and $C$, spatial abundance distribution of southern geoduck in San Matías Gulf. The size of dots represents the visual-guided qualitative scale of density.

growth variation in two beds under exploitation, and to explore the demographic structure of geoducks sampled in previously non-fished beds. We also derived estimates of the natural mortality rate from the age composition in three beds, summarized the main information derived from surveys and periodic samplings and described the spatial fishing effort allocation of the fleet, together with the sources of variability involved in the catch-per-unit-effort (CPUE) estimator.

\section{MATERIALS AND METHODS}

\section{Study area}

San Matías Gulf is a semi-enclosed basin that communicates partially with the open sea through a shallow sill (60 m depth) that limits water exchange (Rivas and Beier, 1990). Its surface area is $19700 \mathrm{~km}^{2}$ and its maximum depth $180 \mathrm{~m}$ (Mazio and Vara, 1983). Water circulation in the gulf is dominated by two eddies, one with the cyclonic gyre in the north and the other with the anticyclonic gyre in the south. An intense thermohaline front divides water into two masses with different oceanographic conditions: relatively cold-fresh waters similar to open shelf waters occur south of the front, whereas warm-salty waters lie north of the front (Piola and Scasso, 1988) (Fig. 1). Waters from the NW and NE coasts are separated by the long sandy ridges around the mouth of San Antonio Bay, and influenced by tidal currents (Lanfredi and Pousa, 1988). The average tidal amplitude is $7.62 \mathrm{~m}$ (maximum $9.2 \mathrm{~m}$ ). The water temperature ranges, on average, from $10^{\circ} \mathrm{C}$ in August (winter) to $18.2^{\circ} \mathrm{C}$ in January (summer) at 20 $\mathrm{m}$ depth. The bottom sediment is dominated by sand near the coast line and gradually mixed with shell fragments, gravel and mud. Muddy sediment is predominant beyond $50 \mathrm{~m}$ depth.

\section{Spatial distribution}

Between 2000 and 2003, two exploratory surveys were conducted in the NW and SW of San Matías Gulf to locate concentrations of geoducks (Fig. 1A). The searching area extended for $94.2 \mathrm{~km}$ along the coastline and $1500 \mathrm{~m}$ offshore. Transects (89) were perpendicular to the coast, spaced $927 \mathrm{~m}$ apart $(0.5$ nautical miles), and ranged between 8 and $35 \mathrm{~m}$ depth. A diver mounted on an iron sledge was slowly trawled on the bottom along transects looking for the tip of the geoduck siphon or for depressions in the bottom. The scope of the visual field was one meter at each side of the transect. When concentrations of geoduck were detected, a grid was defined to estimate the extent of the bed (distance between sampling points was approximately $300 \mathrm{~m}$ ). Since the accuracy of the density estimation is affected by the "show factor", the abundance was visually estimated using a qualitative scale ranging from 0 to 4 , representing an increasing scale of density: 0: absence; 1: scattered tips (less than 1 tip/ $\left.\mathrm{m}^{2}\right) ; 2: 1-3 \mathrm{tips} / \mathrm{m}^{2} ; 3: 4-6 \mathrm{tips} / \mathrm{m}^{2} ; 4$ : maximum density (more than $6 \mathrm{tips} / \mathrm{m}^{2}$ ).

At each concentration detected (2-4 in the qualitative scale), between 152 and 220 geoducks were randomly obtained by SCUBA diving. Divers used an onboard water pump and a hand-held water-jet with a nozzle at the end of the hose to dig out clams one at a time (we give more details of the geoduck capture method in the next CPUE section). Shell size (length, $\mathrm{Lt}$ ) and total weight were recorded. Valves from El Sótano, Punta Colorada and Puerto Lobos were stored for ageing purposes.

\section{Age and growth models}

Individual growth was modeled in two localities, one from the NW coast (El Sótano) and another one from the SW coast (Puerto Lobos) (Fig. 1 B,C), using size-at-age data derived from inner shell layers following deposition periodicity patterns and growth increments defined by Morsan and Ciocco (2004). They described that the thin section of the geoduck shell shows the inner layers as a pattern consisting of a succession of alternating translucent and opaque regions. The periodicity of deposition was determined by analyzing the transparency of the section border of periodically collected individuals. They found that the pattern composed of one wide opaque region and one 
narrow translucent region comprises a yearly cycle of shell growth. We assumed the same periodic pattern to analyze all shells processed in this study.

Right valves collected during the surveys were used for ageing purposes. Thin sections were obtained by cutting the valves with a low-speed diamond saw across the hinge plate. The internal section of the valve obtained from the first cut was ground and polished on a platform with variable speed using very fine grain sandpaper (4000 grit). The polished surface was mounted on a microscope slide using cyanocrylate adhesive. A thin section of $0.5 \mathrm{~mm}$ was obtained from a second cut. The thin section was ground and polished again with medium-grain (1000 grit) and very fine grain (4000 grit) sandpaper until the proper thickness and texture were achieved. The preparation thus obtained was observed under a dissecting microscope with transmitted light to establish the optic pattern of internal growth bands. Growth parameters were described using the von Bertalanffy growth model for both data sets,

$$
L_{t}=L_{\infty}\left(1-e^{-k\left(t-t_{o}\right)}\right)
$$

where $L_{\infty}$ is the asymptotic size (in mm), $k$ the annual growth constant, $t$ the age (years), and $t_{o}$ is the age at size zero.

Growth models were fitted to data using maximum likelihood and compared using a likelihood ratio test (Kimura, 1980; Cerrato, 1990), in order to evaluate differences in growth parameters between El Sótano and Puerto Lobos populations. This method allows several hypotheses to be tested and two curves to be compared by analyzing one or more growth parameters simultaneously. We tested the four following hypotheses:

$$
\begin{gathered}
\text { Ho1: } L_{\infty \mathrm{ES}}=L_{\infty \mathrm{PL}} ; \text { Ho2: } k_{\mathrm{ES}}=k_{\mathrm{PL}} ; \\
\text { Ho3: } L_{\infty}, k_{\mathrm{ES}}=L_{\infty}, k \text { PL } ; \text { Ho4: } \Theta_{\mathrm{ES}}=\Theta_{\mathrm{PL}}
\end{gathered}
$$

where ES and PL denote El Sótano and Puerto Lobos populations, and $\Theta$ is the vector of growth parameters $(L \infty, k$ and $t o)$.

\section{Age structure and mortality}

The age structure of three beds (El Sótano, Punta Colorada and Puerto Lobos) was estimated from geoducks randomly collected and sectioned for age estimation. Natural mortality $(M)$ was estimated using catch curve analysis (Breen, 1991), estimates of longevity (Cranfield et al., 1993) and the Chapman-Robson (CR) estimator (Chapman and Robson, 1960). The catchcurve method estimates $M$ based on a regression of $\ln$ (abundance of each year class) vs estimated age, with the slope of the regression line giving the estimated $M$ (Gribben and Creese, 2005). This method assumes that mortality is constant for all age classes. The proportion of younger geoducks (less than 5 years old) can be underestimated because the small size of their siphons makes it difficult to see them. To prevent this possible bias, regression lines were estimated from age class with maximum frequency onwards. Hypotheses of equal estimations of $M$ between beds were tested by comparing the slope of two regression lines at a time (Kleinbaum and Kupper, 1978).

The second method estimates $M$ using the longevity estimate from the equation:

$$
M=\frac{\ln (p)}{A}
$$

where $A$ is the maximum age reading, and $p$ is the proportion of the population that reaches this age (Cranfield et al., 1993).

The Chapman-Robson estimator is calculated using the catch curve method with the following equation:

$$
C R=\frac{\ln (1+\bar{a}-1 / n)}{\bar{a}}
$$

where $\bar{a}$ is mean age and $n$ is the sample size.

\section{Catch-per-unit-effort (CPUE) estimator and spatial fishing effort allocation of the fleet}

During 1999-2002 five boats began to harvest geoduck in two different locations: El Sótano and Puerto Lobos (Fig. 1). Commercial hookah-divers collect geoducks in a net bag after removing them from the sediment. Divers find geoducks by looking for the siphon tips or for depressions in the bottom. While searching, the diver carries a high pressure water hose called a "stinger." When the diver spots a geoduck he inserts the stinger into the substrate, directs the flow into the sediment around the geoduck and simultaneously grabs the exposed part of the siphon. The diver pulls the geoduck up by the siphon while pushing the stinger deeper if necessary to loosen the soil around the shell of the geoduck. When the bag is full, it is lifted to the surface by a deckhand who manipulates the catch on board, and sends down a new bag. The working area around each boat has an approximate radius of $30 \mathrm{~m}$. When the harvest is finished at the end of the day all boats go back to a fixed point on the beach, which is an improvised port.

Data were recorded by an onboard observer during spring and summer of 2000-2001, taking into account the individual performance of each diver. Divers were identified and catch was recorded as the number of geoducks per bag, and fishing effort as the time taken to fill the bag. These data were integrated at the end of each daily trip as catch in weight, number of geoducks and diving time per diver. In order to compare observed boats with those without an onboard observer, daily fishing effort was also estimated as time over the fishing ground, which extends from the beginning to the end of activities. Catch-per-unit effort (CPUE) was estimated in two different units:

i) $\mathrm{CPUE}_{\mathrm{d}}$ : Number of geoducks caught per bag by any specific diver and fishing time (the number of records is equal to the number of bags lifted on board). 


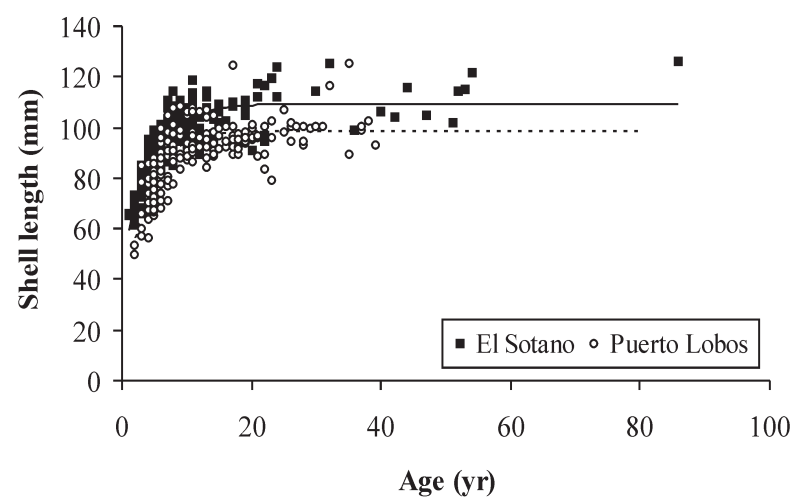

FIG. 2. - Size-at-age and growth models estimated at El Sótano and Puerto Lobos.

ii) CPUE $_{\mathrm{b}}$ : Total weight/number of geoducks caught by all divers and total diving time during the trip (one record per boat).

The spatial allocation of fishing effort is usually patchy, and follows the spatial distribution of abundance. In order to evaluate the spatial variability in yield, three rectangular fishing sites were defined to group the positions. Between-diver variability in CPUE $_{d}$ was evaluated by ANOVA. The Bartlett test was performed to evaluate equality of variances, and the Box-Cox relationship was applied to assess normality and choose adequate transformations.

It is well known that CPUE is highly dependent on the diver's concentration, vision and skill. In order to compare CPUE between sites we chose divers who had harvested at two different sites, and their performance was tested by the Student's t-test. $\mathrm{CPUE}_{\mathrm{b}}$ was used to map the performance of the fleet during the exploratory phase of the fishery (1999 2002), and complement the information taken during surveys. The local fishery administration organized specific forms to be printed for each fishery to track their commercial activities. In the case of the bivalve diving fishery, fishing forms filled out each day are required at the end of each fishing trip. Fishing forms were filled in by the fishermen, detailing fishing time, number of divers and catch (in weight). The number of clams caught was estimated indirectly from the mean individual weight obtained from samples. These data were used to estimate $\mathrm{CPUE}_{\mathrm{b}}$.

\section{RESULTS}

\section{Spatial distribution}

Geoducks are spread widely but have a discontinuous distribution along the coast of San Matías Gulf (SMG). The main aggregations were found on the NW and SW coast of SMG: El Sótano (4056`S), and Puerto Lobos $\left(42^{\circ} 00^{\prime} \mathrm{S}\right)$, and minor concentrations at Punta Colorada ( $\left.41^{\circ} 40^{\prime} \mathrm{S}\right)$ and Punta Pórfido ( $\left.41^{\circ} 46^{\prime} \mathrm{S}\right)$ (Fig. 1B-C). They were arranged in clumps of high density variation. These clumps were aggregated at 6 to $15 \mathrm{~m}$ depth in sandy sediment. Visual estimations of maximum density, derived from the number of siphons, varied from 6 (Punta Colorada) to 8 geoducks $\mathrm{m}^{-2}$ (El Sótano and Puerto Lobos).

\section{Age and growth models}

A total of 421 geoducks were aged and used to model growth at El Sótano $(\mathrm{N}=220)$ and Puerto Lobos $(\mathrm{N}=201)$. Maximum-likelihood growth models of two locations are shown in Figure 2 and growth parameters are summarized in Table 1 . The asymptotic size estimated for El Sótano was higher than it was for Puerto Lobos (Ho1 of likelihood ratio test, $\mathrm{p}<0.001$ ). Only the Ho2 hypothesis (k equal in both populations) cannot be rejected $(p=0.05)$. The estimated models were significantly different when the hypothesis of equality of all parameters was considered (Ho4: $\left.\Theta_{\mathrm{PL}}=\Theta_{\mathrm{ES}}\right)$ in the likelihood ratio test.

\section{Age structure and mortality}

204 clams from Punta Colorada were added to the 421 geoducks aged at El Sótano and Puerto Lobos to plot age structure in these three locations. The geoduck size ranged from $50.28 \mathrm{~mm}$ to $126 \mathrm{~mm}$, and the biggest individuals were found at El Sótano (Fig. 3). The mean weight was $456 \mathrm{~g}$ ( $\mathrm{s}=195.08 \mathrm{~g})$. In general, the age structures were represented mainly by a large number of individuals less than 20 years old (88.4\%). Age ranged from 2 to 86 years, but there were differences between beds (Fig. 4).

The maximum age recorded for each bed decreased from north to south, and the mean age varied between 9.4

TABLE 1. - Parameters of the von Bertalanffy growth model and natural mortality estimation discriminated by location and method (mortality) (upper and lower confidence intervals are shown between brackets).

\begin{tabular}{|c|c|c|c|c|c|c|c|c|}
\hline \multirow[b]{2}{*}{ Site } & \multirow[b]{2}{*}{$L_{\infty}$} & \multirow{2}{*}{$\begin{array}{c}\text { Growth } \\
k\end{array}$} & \multirow[b]{2}{*}{$t_{0}$} & \multicolumn{3}{|c|}{ Natural mortality } & \multirow[b]{2}{*}{$\begin{array}{l}\text { Mean } \\
\text { age }\end{array}$} & \multirow[b]{2}{*}{$\begin{array}{c}\text { Geoducks } \\
\text { aged }\end{array}$} \\
\hline & & & & $\begin{array}{l}\text { Catch } \\
\text { Curve }\end{array}$ & Longevity & $\begin{array}{c}\mathrm{CR} \\
\text { estimator }\end{array}$ & & \\
\hline El Sótano & $\begin{array}{c}109.41 \\
(107.17 ; 111.86)\end{array}$ & $\begin{array}{c}0.230 \\
(0.19 ; 0.27)\end{array}$ & $\begin{array}{c}-2.397 \\
(-3.5 ;-1.59)\end{array}$ & $\begin{array}{c}0.177 \\
(0.128 ; 0.226)\end{array}$ & 0.062 & 0.233 & 10.49 & 220 \\
\hline Punta Colorada & -- & -- & -- & $\begin{array}{c}0.160 \\
(0.136 ; 0.185)\end{array}$ & 0.107 & 0.228 & 9.4 & 204 \\
\hline Puerto Lobos & $\begin{array}{c}98.06 \\
(96.34 ; 99.91)\end{array}$ & $\begin{array}{c}0.305 \\
(0.25 ; 0.37)\end{array}$ & $\begin{array}{c}-0.487 \\
(-1.53 ; 0.25)\end{array}$ & $\begin{array}{c}0.105 \\
(0.072 ; 0.138)\end{array}$ & 0.135 & 0.212 & 12.14 & 201 \\
\hline
\end{tabular}




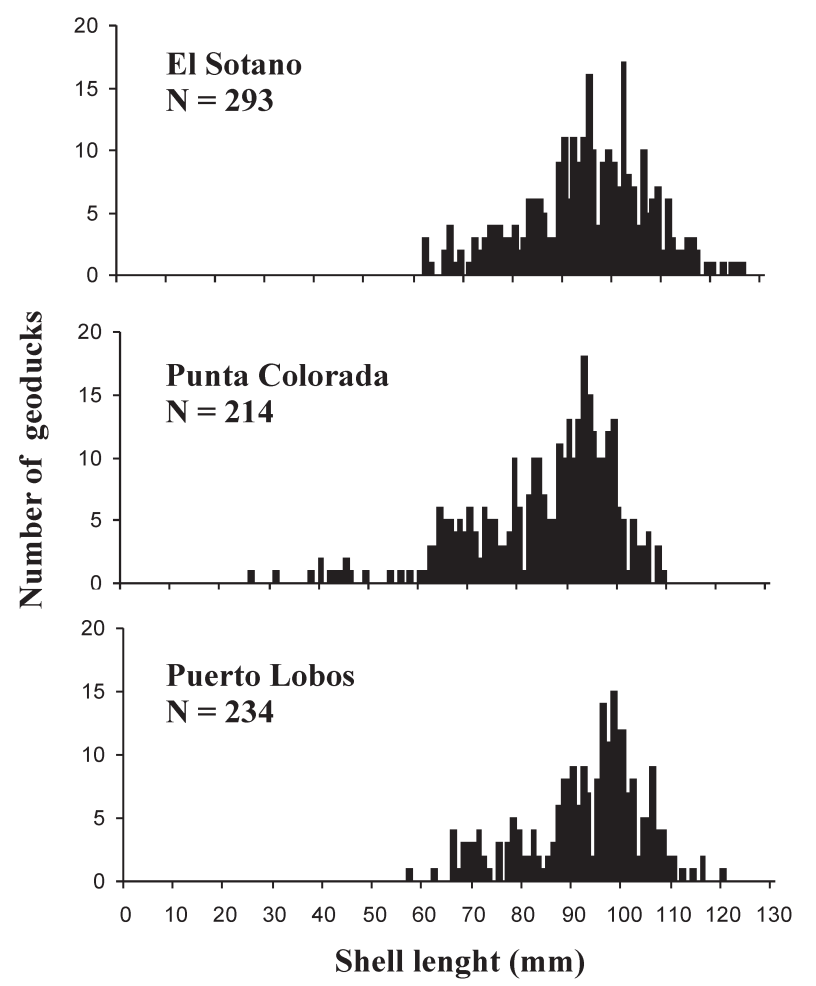

FIG. 3. - Size frequency distribution at three locations in San Matias Gulf.

and 12.14 years (Table 1). These demographic features produced a discrepancy between the estimation based on the maximum longevity recorded, and the ChapmanRobson method, which is based on mean age. The age frequency distribution (AFD) suggests a single negative exponential model of abundance of year classes. We consider that individuals younger than 5 years were not fully sampled, and these were excluded from the estimation. Estimates of instantaneous natural mortality of $P$. abbreviata provided by the catch curve analysis by bed yielded results that varied between $0.177 \mathrm{yr}^{-1}$ and 0.105 $\mathrm{yr}^{-1}$. Populations from El Sótano and Punta Colorada showed no significant differences in estimated natural mortality $(\mathrm{P}=0.533)$. Puerto Lobos differed significantly from the others $(\mathrm{P}<0.05)$.

\section{The catch-per-unit-effort (CPUE) estimator and spatial fishing effort allocation of the fleet}

The geoduck fishery was established at El Sótano, Puerto Lobos and some areas of San José Gulf (SJG) (Fig 1). Market constraints quickly discouraged the fishery in SJG, and the geoduck fishery was sustained by small but increasing landings from the other two areas. During the first year of exploitation the total geoduck landings were $5.7 \mathrm{t}$, and in subsequent years it varied between 1.8 and $15.6 \mathrm{t}$.

The fishing time ranged from 3 to 6 hours during one trip. However, each boat had among 2 to 3 divers

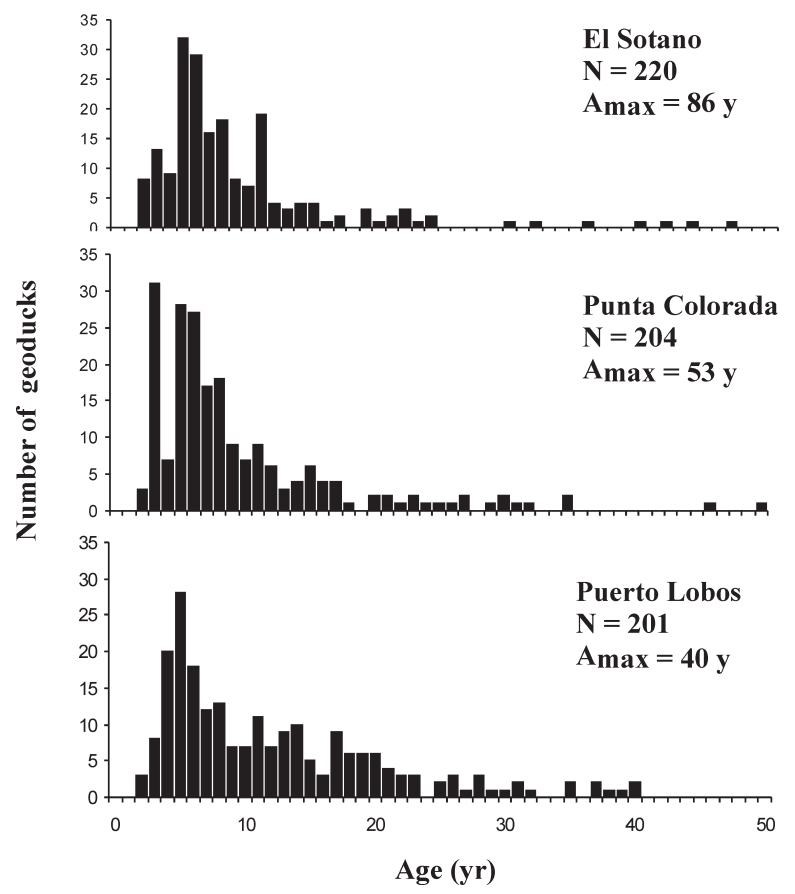

FIG. 4. - Age frequency distribution at three locations in San Matías Gulf $\left(\mathrm{A}_{\max }\right.$ : maximum age recorded).

who can harvest simultaneously. Thus, considering the total diving time spent by three divers, the fishing time would range between 3.7 and 7.6 hours.

The spatial allocation of fishing effort was coincident with dense patches located during surveys (Fig. 5). The CPUE $_{b}$ of five boats varied from 24.6 to $135.1 \mathrm{~kg}$. diver $^{-1}$. time ${ }^{-1}$, and from 61.9 to 304.4 geoducks . diver ${ }^{-1}$

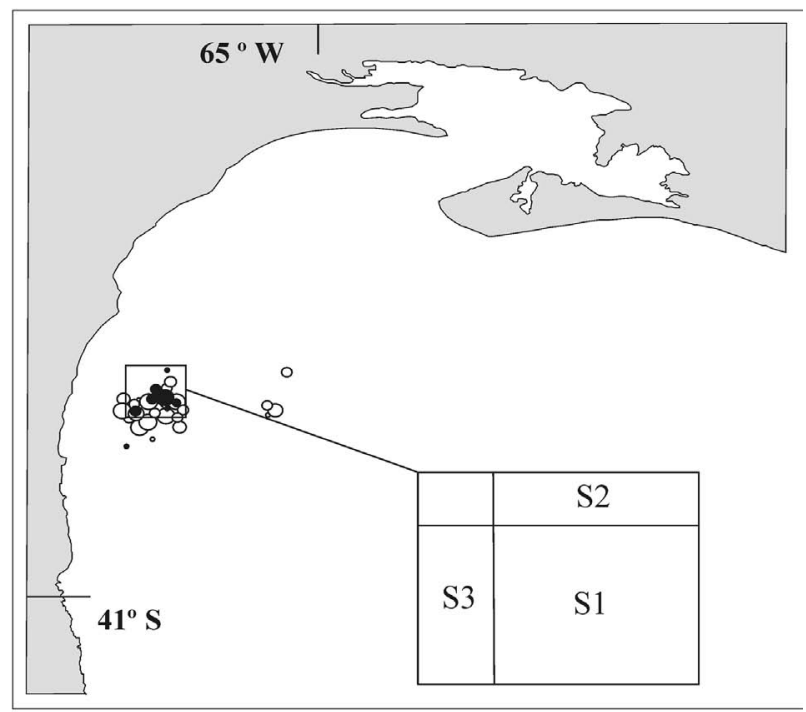

FIG. 5. - Catch per Unit Effort (CPUE) and spatial allocation of fishing effort at El Sótano. Black circles represent fishing position of onboard observer during the preliminary phase of the fishery, and white circles represent those collected from fisherman logbooks. The size of circles is related to the CPUE value. The rectangle corresponds to the area in which the CPUE was considered. The three different locations $(\mathrm{S} 1, \mathrm{~S} 2, \mathrm{~S} 3)$ that were analyzed to contrast mean CPUE at a small spatial scale are represented on the right. 


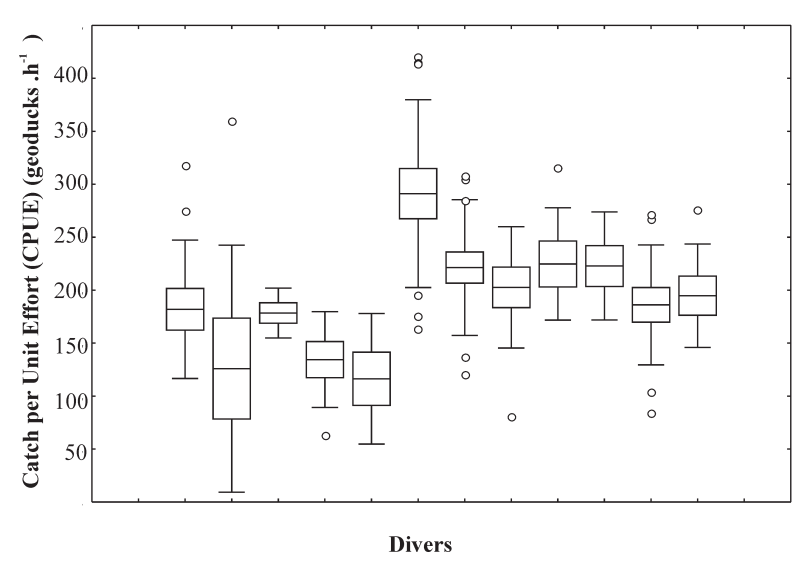

FIG. 6. - Mean Catch per unit Effort $\left(\mathrm{CPUE}_{\mathrm{b}}\right)$ of 12 divers monitored by onboard observer at El Sótano, represented by a horizontal line inside the box. The box limits represent the standard error and the whiskers represent the standard deviation.

. time ${ }^{-1}$. The analysis of $\mathrm{CPUE}_{\mathrm{d}}$, as an indicator of each diver's daily performance, yielded significant differences among 12 divers (Fig. 6; ANOVA, $\mathrm{P}<0.001, \mathrm{n}=138$ ). The Bartlett test allowed the homocedacy hypothesis to be accepted $(\mathrm{P}>0.1)$ and the Box-Cox test suggested that no transformation of data is required. In order to compare the performance of the same diver fishing at different sites, we segregated $\mathrm{CPUE}_{\mathrm{d}}$ into three sites $(\mathrm{S} 1, \mathrm{~S} 2$ and S3) (Fig. 5). The results were: i) all divers fished within $\mathrm{S} 1$, and the $\mathrm{CPUE}_{\mathrm{d}}$ continued to show significant differences among them (ANOVA, $\mathrm{P}<0.001, \mathrm{n}=109$ ); ii) five divers fished within other sites: three at S2 and two at S3. The between-site comparison showed no significant differences in mean $\mathrm{CPUE}_{\mathrm{d}}$ (Fig.7; P>0.05); however, three divers who fished at S1 and S2 had higher $\mathrm{CPUE}_{\mathrm{d}}$ when they fished at S1.

In addition, fishing activities were unrestricted in the area open to fishing, but divers concentrated on the same zone, repeating known sites within an area of approximately $1 \mathrm{~nm}^{2}$. CPUE was recorded per boat and plotted in Figure 6.

During the period from 2001 to 2008 some catches were obtained from Puerto Lobos by 2-3 boats. Fishery data were collected informally and therefore total landings of geoducks were impossible to establish. Daily catches varied from 30 to $540 \mathrm{~kg}$, but boats fished for other species, such as ribbed mussel (Aulacomya atra) and sledge clam (Ensis macha), during the same trip so that it was difficult to accurately measure the fishing effort on geoducks.

\section{DISCUSSION}

Two important pieces of information to study this slow-paced dynamics are: i) age composition that allows interpretation of growth, longevity, mortality rate and recruitment; and ii) the spatial pattern of abundance at different scales. This is especially true in $P$. abbreviata because a significant number of samples were taken before fishing started.

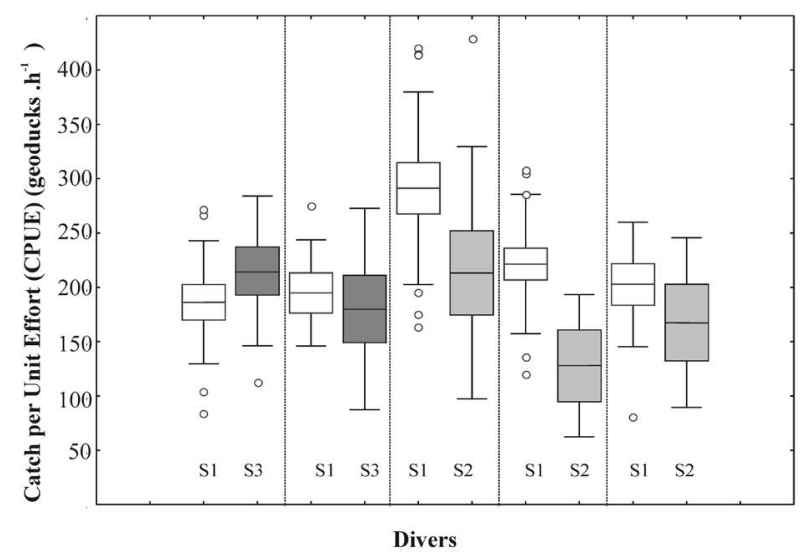

FIG. 7. - Contrast of mean Catch per unit Effort $\left(\mathrm{CPUE}_{\mathrm{b}}\right)$ among five divers who fished at site $\mathrm{S} 1$ (white boxes) and another two sites (grey boxes) represented by a horizontal line inside the box. The box limits represent the standard error and the whiskers represent the standard deviation.

Age determination was described by Morsan and Ciocco (2004) using the internal growth lines on thin sections of valves. The seasonal cycle of shell layers consisting of a translucent region formed during winter and an opaque region deposited from spring to fall. This was attributed to conditions of apparent inactivity during winter when geoducks retract their siphons, probably as a consequence of low temperatures and food availability which may affect their metabolic rate. The southern geoduck grows rapidly during the first 9 to 12 years, when the clams may reach $90 \%$ of their maximum size, then after this time growth is very slow. The results of individual growth patterns showed differences between two populations located to the north and south of SMG, on the two sides of the thermohaline front. These patterns differ in asymptotic size and may be derived from oceanographic conditions of two water masses: the warmer and saltier waters of the northern sector and the colder and less salty waters that enter from the south, coming from the continental shelf and San José Gulf (Gagliardini and Rivas, 2004). Piola and Scasso (1988) found that there is a zonal front situated near $41^{\circ} 50$ 'S during most of the year, which generates a difference in temperature between the two regions of up to $3^{\circ} \mathrm{C}$, which becomes negligible in winter.

Geoducks are probably among the most long-lived of exploited animals, with a potential life of more than one hundred years. Determining longevity in longlived animals depends largely on having a sample size that is likely to include the oldest individuals, which are not very abundant in the population. The maximum recorded age for $P$. abrupta is 168 years old (Bureau et al., 2002), in a sample size of thousands of individuals. In the first study on age of the southern geoducks, Morsan and Ciocco (2004) estimated a maximum age of 40 years from a sample of 104 valves. In this study we analyzed the age composition of the southern geoduck for the first time, ageing 628 individuals collected from three beds, and found a maximum age of about 
86 years. Even though $P$. abbreviata is less long-lived than $P$. abrupta, there is an evident difference in the detection capacity and longevity of $P$. abbreviata that could be modified if new beds are discovered and more individuals are aged.

The natural mortality estimation of $P$. abbreviata varies widely in relation to the method used. The maximum estimate of $M$ was obtained when mean age was used and the minimum estimate when a method based on maximum age was used. Estimates derived from age frequency distributions ("catch curve methods"), the most commonly used approach, are based on the assumption of stable recruitment. In the case of geoducks, possible bias derived from this assumption can be compensated for by a wide geographical range and the coexistence of a large number of age classes. But this method leads to circularity and can be biased in relation to long-term trends in recruitment (Orensanz et al., 2004). Studies on geoduck (Panopea abrupta) populations from the NE Pacific have revealed a striking large-scale geographic coherence in long-term recruitment trends (Orensanz et al., 2000; Orensanz et al., 2004). A marked, several-decade decline followed by a rebound around the mid 1970s affected a vast geographic region from Queen Charlotte Is. (British Columbia, Canada) to Puget Sound (Washington, USA).

The age structure of the southern geoduck showed low abundance of annual classes of juveniles. This could be caused by an underestimation of frequencies of juveniles with small-sized siphons. Despite this, the age structures were dominated by individuals less than 20 years of age, which could represent a possible expansion of the metapopulation over the last two decades. Moreover, in the northernmost bed (El Sótano) there were individuals that reached 86 years of age, and the maximum age decreased from north to south (Fig. 4). This scenario suggests that the age frequency method is more reliable than other methods, but is affected by a spatial-temporal variation in recruitment. In order to avoid these problems Orensanz et al. (2004) developed a taphonomic method based on ageing "cluckers", empty shells left in situ after animals die. The outcome of this method is an independent estimation of natural mortality that allows a recruitment time series to be reconstructed.

As for other sedentary species, these dynamic processes need to be studied in connection with the spatial pattern. Analysis of the spatial dimension of population processes requires identification of meaningful scales (Orensanz and Jamieson, 1998).

Geoducks share many spatial distribution characteristics with other bivalves, like aggregation in clusters and temporal changes in abundance (Fegley, 2001). On broad spatial scales, P. abbreviata are found as spatially disjunct subpopulations in muddy and sandy sediment parallel to the coastline, but their spatial distribution is highly variable on several scales. This was evidenced by the complementary contribution of fishery-independent surveys describing the position of beds on a geographic scale and by fishery-dependent data such as spatial effort allocation and the performance of divers. When there is a spatial pattern of abundance, the fishing effort tends to concentrate on the areas with highest abundance, depleting them gradually (Caddy 1975, 1979). However, the fishery data analyzed here were collected at the beginning of the harvest, without the temporal component. Boats concentrated on a small area of El Sótano which ensures fishermen good yields, a short distance from coast and brief navigation time. Variability in $\mathrm{CPUE}_{\mathrm{d}}$ among divers suggests variation in abundance on a small scale, but it could be influenced by several factors, like skill in seeing the tip of the siphon, skill in removing and handling the individuals, divers' tiredness during a working day, weather conditions, transparency of sea water and work schedule (a fishing day usually started with two divers and one of them was replaced by a third diver after 1-2 hours).

During the period 2006 to 2008, $\mathrm{CPUE}_{\mathrm{b}}$ showed no trend and was affected by additional commercial factors that forced fishermen to divide their daily fishing time to harvest other species. In terms of describing fishery processes, CPUE is generally considered to be a poor indicator of abundance in sedentary resources as these are contagiously distributed (Hilborn and Walters, 1992; Prince and Hilborn, 1998). In this case, CPUE and its relation with abundance are directly affected by the vision-guided movement of the diver who can recognize patterns and allocate efforts accordingly. CPUE can remain stable at high values while depletion takes place, or (if there are few dense patches and these are small) it can drop quickly without reflecting an equivalent change in abundance (Orensanz et al., 1998). The former is called "hyperstability" and Campbell et al. (1998) described this type of relationship for the $P$. abrupta fishery in British Columbia, where only when geoduck density declined below 0.5 geoducks. $\mathrm{m}^{-2}$ did CPUE start to decline rapidly, and above that density it remained stable.

Geoducks surveyed over large areas are linked to uncertainty about actual biomass due to their highly patchy spatial distribution and the difficulty of detecting individuals. Siphon visualization depends on the type of sediment, season, or the diver's skill, which makes it difficult to apply certain correction factors over a large area with heterogeneous conditions. This makes it difficult to establish management measures that are applied in other similar fisheries, such as harvest rate. In this study, we focused on the macroscale distribution and AFD in order to estimate the natural mortality at the beginning of harvesting. AFD are informative about stock dynamics on a longer time-scale than that required by management response. These features were integrated into a preliminary management proposal that was based on:

- Subdividing the west coastal zone of the gulf into areas to be managed independently based on the presence of juveniles, density and other activities (marine cultures, harvesting of other bivalve species). 
- Limiting entry by fixing the number of permits to access geoduck fishing areas.

- Carrying out surveys for estimating biomass with the participation of fishermen. Currently, only a qualitative estimation of density has been made, and the actual biomass has never been estimated.

- Establishing a harvest rate and associated individual vessel quotas (IVQs).

In this way, the bed of El Sótano would be preserved to be exploited with high control, and the harvest stopped when a certain threshold density is reached in order to maintain the chances of fertilization. Monitoring an experimental plot would provide the possibility to evaluate the population's response to exploitation.

These measures are included in a philosophy that intends to incorporate fishermen into management discussions and thus promote a bottom-up approach based on ideas such as biological sustainability, co-management, adequate incentives, and diversification of artisanal fishery activities that would relax the effort on the limited resources and consider alternative actions that take into account uncertainty about recruitment, the market, environmental contingency and variation in life-history parameters.

\section{ACKNOWLEDGEMENTS}

This study was supported by PNUD Ar 02/018. The authors thank Juan Pablo Rubinich, Laura Del Grosso and Norberto De Garin for their help in the fishery and survey data collection, Sandro Acosta, Nestor Dieu and Pablo Sacco for diving assistance, and Nelly Horák for collaboration in the English translation.

\section{REFERENCES}

Bradbury, A. and J.V. Tagart. - 2000. Modelling geoduck, Panopea abrupta (Conrad, 1849) population dynamics. II. Natural mortality and equilibrium yield. J. Shellfish Res., 19: 63-70.

Bradbury, A., B. Sizemore, D. Rothaus and M. Ulrich. - 2000. Stock Assessment of Subtidal Geoduck Clams (Panapea abrupta) in Washington. Washington State Department of Natural Resources and Washington State Department of Fish and Wildlife: 1-61.

Breen, P.A. - 1991. The New Zealand deepwater clams (geoducks) Panopea zelandica and P. smithae. N.Z. Fish. Assess. Res. Doc. 91/5: 1-13.

Bureau, D., W. Hajas, N.W. Surry, C.M. Hand, G. Dovey and A. Campbell. - 2002. Age, size structure and growth parameters of geoducks (Panopea abrupta, Conrad 1849) from 34 locations in British Columbia sampled between 1993 and 2000. Can. Spec. Publ. Fish. Aquat. Sci., 2413: 1-84.

Caddy, J.F. - 1975. Spatial model for an exploited shellfish population, and its application to the Georges Bank scallop fishery. $J$. Fish. Res. Board. Can., 32(8): 1305-1328.

Caddy, J.F. - 1979. Some considerations underlying definitions of catchability and fishing effort in shellfish fisheries, and their relevance for stock assessment purposes. Fisheries and Marine Service. MS Report $\mathrm{N}^{\circ} 1489$.

Campbell, A., R.M. Harbo and C.M. Hand. - 1998. Harvesting and distribution of Pacific geoduck clams, Panopea abrupta, in British Columbia. In: G.S. Jamieson and A. Campbell (eds.), Proceedings of the North Pacific Symposium on invertebrate stock assessment and management. Can. Spec. Publ. Fish. Aquat. Sci., 125: 349-358

Cerrato, R.M. - 1990. Interpretable statistical test for growth comparison using parameters in the von Bertalanffy equation. Can
J. Fish. Aquat. Sci., 47: 1416-1426.

Chapman, D.G. and D.S. Robson. - 1960. The analysis of a catchcurve. Biometrics, 16: 354-368.

Ciocco, N.F. - 2000. Almeja panopea, un nuevo recurso pesquero para el Mar Argentino. Infopesca Inter., 6: 36-39.

Ciocco, N.F., N. de Garin, M.A. Diaz, R. Vera, R. Mazzanti, M.A. Monsalve, G. Herrera, S. Sollazo, A. Serda, D. Diaz, C. Signorelli, J. Lopez, J. Ascorti, R. Diaz, M.C.Bazterrica, G. Escati and L. Real. - 2001. Relevamiento de bancos de moluscos bivalvos de interés marisquero en el golfo San José. Resultados de la campaña Sanjo/01. Acta Complementaria Convenio Provincia del Chubut- CENPAT-CONICET Ley 3315. Inf. No 11 del LAPEMAR, Laboratorio de Peces y Mariscos de Interés Comercial (CENPAT): 1-69.

Cranfield, H. J., K.P. Michael and D.R. Stotter. - 1993. Estimates of growth, mortality, and yield per recruit for New Zealand surf clams. N.Z. Fish. Assess. Res. Doc., 93/20: 1-26

Fegley, S. - 2001. Demography and dynamics of hard clam populations. In: J. Kraeuter and M. Castagna (eds.), Biology of the Hard Clam, pp. 383-422. Elsevier, New York.

Gagliardini, D.A. and A.L. Rivas. - 2004. Environmental characteristics of San Matías Gulf obtained from LANDSAT-TM and ETM+ data. Gayana, 68(2) (supl. t.I. Proc.): 186-193.

Goodwin, L. and B.C. Pease. - 1989. Species profiles: life histories and environmental requirements of coastal fishes and invertebrates (Pacific Northwest): Pacific geoduck clam. U.S. Fish. Wildlife Serv. Biol. Rep., 82: 11-120.

Gribben, P.E. and R.G. Creese. - 2005. Age, growth, and mortality of the New Zealand geoduck clam, Panopea zelandica (Bivalvia: Hiatellidae) in two north island populations. Bull. Mar. Sci., 77(1): 119-135.

Hilborn, R. - 2002. The dark side of reference points. In: F. Coleman and J. Travis (eds.), Target, Thresholds and the Burden of Proofs. Bull. Mar. Sci., 70: 403-408.

Hilborn, R. and C.J. Walters. - 1992. Quantitative fisheries stock assessment. Chapman and Hall, New York, N.Y.

Hoffmann, A., A. Bradbury and L. Goodwin. - 2000. Modeling Geoduck, Panopea abrupta (Conrad, 1849) Population Dynamics. I. Growth. J. Shellfish Res., 19(0): 57-62.

Kimura, D.K. - 1980. Likelihood methods for the estimation of the von Bertalanffy growth curve. Fish. Bull., 77: 765-776.

Kleinbaum, D.G. and L.L. Kupper. - 1978. Comparing two straightline regression models. In: D. Kleinbum, and L. Kupper (eds.), Applied regression analysis and other multivariate methods, $\mathrm{pp}$. 95-112. Duxbury Press, North Scituate, Massachusetts.

Leal, G.A., J.B. Dima, F. Dellatorre and P. Barón. - 2008. Schedule of Reproductive Events and Maturity at Size of the Patagonian Stone Crab Platyxanthus patagonicus (Brachyura, Platyxanthidae). J. Crustac. Biol., 28(2): 262-269.

Lanfredi, N.W and J.L. Pousa. - 1988. Mediciones de corrientes, San Antonio Oeste, Provincia de Río Negro. Instituto de Biología Marina y Pesquera “Alte. Storni”, Río Negro, Argentina, Tech. Rep., 13 pp.

Mazio, C. and C. Vara. - 1983. Las mareas del Golfo San Matías, Argentina., Servicio de Hidrografía Naval. Dpto. Oceanografía, Tech. Rep., 69 pp.

Morsan, E.M. - 2003. Spatial analysis and abundance estimation of the southernmost population of purple clam, Amiantis purpurata in Patagonia (Argentina). J. Mar. Biol. Ass. U.K., 83(5): 1115-1128.

Morsan, E.M. - 2007. Spatial pattern, harvesting and management of the artisanal fishery for purple clam (Amiantis purpurata) in Patagonia (Argentina). Ocean Coast Manage., 50: 481-497.

Morsan, E.M. - 2008. Impact on biodiversity of scallop dredging in San Matías Gulf, northern Patagonia (Argentina). Hydrobiologia, 609: 167-180.

Morsan, E. M. and N.F. Ciocco.- 2004. Age and growth modelling of the southern geoduck Panopea abbreviata off Puerto Lobos (Argentina). Fish. Res., 49(3): 343-348.

Narvarte, M.A. - 2005. Biology and fishery of the whelk Buccinanops globulosum (Kiener, 1834) in northern coastal waters of the San Matías Gulf (Patagonia, Argentina). Fish. Res., 77: 131-137.

Orensanz, J.M. and G. Jamieson. - 1998. The assessment and management of spatially structured stocks: an overview of the North Pacific Symposium on invertebrate stock assessment and management. In: G.S. Jamieson and A. Campbell (eds.), Proceedings of the North Pacific Symposium on invertebrate stock 
assessment and management. Can. Spec. Publ. Fish. Aquat. Sci., 125: 441-459.

Orensanz, J.M., A.M. Parma and M. Hall - 1998. The concentration and crowding in shellfish research. In: G.S. Jamieson and A. Campbell (eds.), Proceedings of the North Pacific Symposium on invertebrate stock assessment and management. Can. Spec. Publ. Fish. Aquat. Sci., 125: 143-157.

Orensanz J.M., R. Hilborn and A.M. Parma. - 2000. Harvesting Methuselah's clam-Is the geoduck fishery sustainable, or just apparently so? Canadian Stock Assessment Secretariat (CSAS), Res. Doc. 2000/175: 1-68.

Orensanz, J.M., C. Hand, A.M. Parma, J. Valero and R. Hilborn. - 2004. Precaution in the harvest of Methuselah's clams-the difficulty of getting timely feedback from slow-pace dynamics. Can. J. Fish. Aquat. Sci., 61: 1355-1372.

Orensanz, J.M., A.M. Parma, G. Jerez, N. Barahona, M. Montecinos and I. Elías. - 2005. What are the key elements for the sustainability of "S-fisheries"? Insights from South America. In: N. Erhardt (ed.), The Scientific Bases for the Sustainability of Fisheries. Bull. Mar. Sci., 76: 527-556.

Piola, A.R. and L.M. Scasso. - 1988. Circuación en el Golfo San Matías. Geoacta, 15: 33-51.

Prince, J. and R. Hilborn. - 1998. Concentration profiles and invertebrate fisheries management. In: G.S. Jamieson and A. Campbell (eds.), Proceedings of the North Pacific Symposium on invertebrate stock assessment and management. Can. Spec. Publ. Fish. Aquat. Sci., 125: 187-196.

Pritchett, M. - 2003. Geoduck clam stock assessment surveys and fisheries management for the 2002/2003 season. Alaska Department of Fishes and Game, Division of Commercial Fisheries, Regional Inf. Rep. 1J02-47: 1-78

Rivas, A.L. and E.J. Beier. - 1990. Temperature and salinity fields in the Northpatagonic Gulfs. Oceanol. Acta, 13(1): 15-20.

Scarabino, V. - 1977. Moluscos del Golfo San Matías (Prov. Rio Negro, Argentina). Inventario y claves para su identificación. Com. Soc. Malac. Uruguay, IV(31-32): 177-297

Siddon, C. - 2007. Evaluation of the Southeastern Alaska Geoduck (Panopea abrupta) Stock Assessment Methodologies. Alaska Dep. Fish. Game Spec. Publ., 7-2: 1-14.

Strom, A. - 2003. Climate and fisheries in the Pacific Northwest: historical perspective from geoduck and early explorers. MSc thesis, Univ. Washington.

Van der Molen, S., M. Kroeck and N.F. Ciocco. - 2007. Reproductive cycle of the southern geoduck clam, Panopea abbreviata (Bivalvia: Hiatellidae), in north Patagonia, Argentina. Invert. Reprod. Develop., 50(2): 75-84.

Scient. ed.: J. Templado

Received July 27, 2009. Accepted March 10, 2010.

Published online September 22, 2010. 